\title{
Nexus Between Foreign Direct Investment And Manufacturing Output In India: An ARDL Approach
}

Pratap Kumar Jena ( $\square$ jenapratapkumar@gmail.com )

Maharaja Sriram Chandra Bhanjadeo University https://orcid.org/0000-0001-7963-2091

Runu Lata Sahoo

Maharaja Sriram Chandra Bhanjadeo University

Research

Keywords: FDI, Manufacturing output, Augmented ARDL, Economic growth

Posted Date: February 15th, 2022

DOI: https://doi.org/10.21203/rs.3.rs-1133600/v1

License: (c) (i) This work is licensed under a Creative Commons Attribution 4.0 International License. Read Full License 


\section{Abstract}

In view of the importance of foreign direct investment (FDI) on the growth of manufacturing output, this paper examines the nexus between FDI and manufacturing output in India using the autoregressive distributed lag (ARDL) bound test. The empirical results indicate that a high positive correlation presents between FDI and manufacturing output during the study period. The ARDL bound test results indicate the existence of a long-run relationship between FDI and manufacturing output in the study period. The ARDL-VECM model suggests the existence of short-run relationship between the two variables. In view of the fact that the manufacturing sector is one of the important sectors in India for employment and economic growth, there must be policy implication by the government to boost the manufacturing output in the country.

JEL Classification: C22, F31, 047

\section{Introduction}

In recent years, India is one of the most eye-catching destinations for investments in the manufacturing sector in the world. Investment is crucial for industrialization in a country, due to inadequate domestic investment, foreign direct investment (FDI) has been attracted to the industries to foster the manufacturing output, employment and economic growth (Hussain and Haque, 2016). Developing countries have been trying to attract more FDI to different sectors (Epaphra \& Massawe, 2017). Besides that, the FDI enhances skills and advanced technology, productivity and standard of living in the long-run (Kobrin, 2005). The FDI has a spillover effect on the macroeconomic variables, which finally enhances economic growth (Eregha, 2012). It has been recorded that the FDI has increased at a significant rate in the post-reform period and achieved new heights during the $20^{\text {th }}$ century. India is ranked among the top 10 recipients of FDI in South Asia, which has attracted US \$49 billion (UNCTAD, 2019). The cumulative FDI in India's manufacturing sector reached US $\$ 89.40$ billion 2000 to 2020, and the govt. of India has increased FDI from $49 \%$ to $74 \%$ on defense manufacturing under the automatic route (Indian Industry Report, 2020).

Policy makers and academic researchers at the international level have been examined the linkage between the FDI and manufacture output, but there is a lack of literature for India. Turkan et al., (2008) and Agrawal (2005) have found a positive relation between FDI, manufacturing sector and economic growth. On the other hand, Oyatoye et al. (2011) obtained a poor attraction of FDI to the Nigerian economy, and the FDI had little or no impact on the manufacturing capacity utilization in Nigeria. Afolabi et al. (2019) analysed the connection between the Nigerian manufacturing sector and FDI and found that the manufacturing out was influenced by FDI and other macroeconomic variables such as Inflation rate (INF), government expenditure (GOE), and money supply (MSP). That is because the FDI in the manufacturing sector is negatively influenced by different factors such as; import-intensity, $R \& D$ intensity, and positively influenced by the market power (Hooda, 2011). India is one of the most attractive destinations of FDI in the world, which can be achieved through quick project clearance, improving 
coordination between the states and the central government for project clearance is imperative by making SEZs more attractive, proper planning and design (Mohanty and Sethi, 2019). The relationship between FDI, manufacturing sector and economic growth is inconclusive as studies derive different results.

From the existing studies, it is not clear on the relationship between foreign direct investment (FDI) and the manufacturing sector in India, Therefore, this paper is examining the relationship between FDI and the manufacturing sector in India at a disaggregated level with emphasis on implications for capital formation in the sector and market structures. The rests of the paper are as follows; section-2 describes the composition, market size and performance of the manufacturing sector in India. Section-3 provides study variables and methodology. Section-4 discusses the estimated results, and the last section-5 provides the conclusion of the study.

\section{Manufacturing Sector In India: Composition, Market Size And Performance}

In pre-independence, India was exporting huge quantities of manufacturing products, most of them were handicraft products that have been declined due to the regressive policies of the government (Kathuria, 1986). After independence, the government has implemented the industrial policy in 1956, and there was the development of basic and heavy industries such as iron \& steel, heavy engineering, lignite projects, and fertilizer, etc. The new economic policy has increased the competition of domestic products in the international markets.

The India Brand Equity Foundation (IBEF) has categorized the manufacturing industries based on size, and use of inputs or raw materials (IBEF Report, 2019). The size of manufacturing industries depends on capital investment, workers employed and quantities production, such industries are household or cottage industries (includes bamboo, leather, wood, bricks, fabrics, stones, mud materials, etc.), small scale manufacturing industries (workshop outside home or cottage production), and large scale manufacturing industries (includes superior technology, large capital, large production, etc). The second type of classification was based on the use of inputs or raw materials, and such industries are agrobased industries (includes rural and urban businesses like; food processing, fruits juices, pickles, beverages, cotton, silk, etc.), food processing (includes the production of cream, canning, confectionary, and fruits), mineral-based industries (includes iron \& steel industries and non-ferrous metallic minerals like cooper, aluminium \& jewellery, etc), chemical-based industries (like sulphur, potash, synthetic fibre, plastics, etc.), forest-based raw material using industries (includes; minor and major forest products, wood and grass, etc.), and animal-based industries includes leather and wool industries, etc.

Market Size and Performance: India has ranked $30^{\text {th }}$ in the global manufacturing index in 2018 , and the gross value added (GVA) of the manufacturing sector at basic prices was US\$ 403.23 billion in the financial year 2019 (World Economic Forum, 2019). The compound annual growth rate (CAGR) of GVA in manufacturing sector was recorded at $4.29 \%$ during the financial year 2012-19. The index of industrial production (IIP) of manufacturing sector grew at $3.50 \%$, where the high growth rate was recorded in the 
production of basic metals, intermediate goods, food products, and tobacco products (DES, 2017). The gross fixed capital formation (GFCF) or net investments in fixed assets was US\$, 405.88 billion in 201920 , and was expected that it may touch US $\$ 1$ trillion by the end of 2025 (MOSPI, 2020).

It has been observed that the contribution of the manufacturing sector to India's GDP was $6.8 \%$ in 2018 , whereas, the contribution to world GDP was $3 \%$, which suggests that the manufacturing sector has a significant contribution to the national income of India (World Bank, 2019). The growth rate of the manufacturing sector and the economic growth rate during 1991 to 2018 are reported in Figure-1, which indicates that both growth rates have fallen after 2007 and have more volatility, but FDI is more volatile than the GDP growth rate in the study period, that makes worrisome to the policymakers in India.

The manufacturing output has various uses, which is broadly categorized into six uses such as primary goods (34\%), capital goods ( $8 \%)$, intermediate goods (17\%), infrastructure/construction goods (13\%), consumer durables (13\%) and consumer non-durable goods (15\%). It indicates that the manufacturing outputs are largely used as primary goods followed by intermediate goods, and the least output is used in capital goods in India (Figure-2).

Figure-3 draws the picture of Gross Value Added and Employment growth rate of manufacturing industries from 1987-88 to 2017-18. And found that GVA has been rising steadily over the years witnessing a growth rate of $62.8 \%$ in $2017-18$. The growth rate of employment has been relatively lower i.e. $3.8 \%$ in $2017-18$.

The compound annual growth rate (CAGR) of major manufacturing product industries in India during the period 2012-13 to 2017-18 is reported in Table-1. It shows that the Tobacco products industry has the highest CAGR (2.48\%), followed by other manufacturing industries (1.27 percent) and electrical equipment (1.02 percent). The wood, and products of wood \& cork, except furniture of articles had a positive CAGR (0.98 percent). All other manufacturing industries have a negative compound growth rate but the pharmaceutical, medicinal products, and botanical products, and furniture had a larger negative CAGR during 2012-13 to 2017-18 in India.

Table 1: Compound Annual Growth Rate of Major Manufacturing Industries in India 
Industry group

Food products

Beverages

Tobacco products

Textiles

Wearing apparel

Leather and related products

Wood and products of wood and cork, except furniture of articles

Paper and paper products

Printing and reproduction of recorded media

Coke and refined petroleum products

Chemicals and chemical products

Pharmaceuticals, medicinal chemical, and botanical products

Rubber and plastic products

Other non-metallic mineral products

Basic metals

Fabricated metal products, except machinery and equipment

Computer, electronic and optical products

Electrical equipment

Machinery and equipment

Other transport equipment

Motor vehicles, trailers and semi-trailers

furniture

Other manufacturing

Manufacturing

Source: Hand Book of Statistics, RBI
2012- 2017- CAGR (2012-13 to

13

18

2017-18)

$103.3 \quad 108.1 \quad-0.90 \%$

$106.7 \quad 105.4 \quad 0.25 \%$

$107.5 \quad 95.1 \quad 2.48 \%$

$108 \quad 117.1 \quad-1.60 \%$

$99 \quad 137.5 \quad-6.36 \%$

$110.6 \quad 123.9 \quad-2.25 \%$

$\begin{array}{lll}97 & 92.4 \quad 0.98 \%\end{array}$

$103.3 \quad 108.9-1.05 \%$

$96.8 \quad 99.7 \quad-0.59 \%$

$105.9 \quad 123.5 \quad-3.03 \%$

$103.9 \quad 116 \quad-2.18 \%$

$108.1 \quad 212.1 \quad-12.61 \%$

$101 \quad 110.6 \quad-1.80 \%$

$102.9 \quad 113.9 \quad-2.01 \%$

$107.8 \quad 138 \quad-4.82 \%$

$97 \quad 107.9 \quad-2.11 \%$

$100.6 \quad 148.5 \quad-7.49 \%$

$113 \quad 107.4 \quad 1.02 \%$

$102.9 \quad 120.5 \quad-3.11 \%$

$99.2 \quad 133.9 \quad-5.82 \%$

$100.1 \quad 114.5 \quad-2.65 \%$

$112.9 \quad 196.6 \quad-10.50 \%$

$113.1 \quad 106.2 \quad 1.27 \%$

$104.8 \quad 126.6 \quad-3.71 \%$ 


\section{Data And Methodology}

The relationship between FDI and the manufacturing output in India is examined using the time series data, collected from the handbook of statistics on the Indian Economy, the Reserve Bank of India (RBI), and the National Sample Survey Organisation (NSSO) database. The FDI is collected in Indian rupees crore, whereas for the manufacturing output, we have used manufacturing output index. Since, the variables are in different units, we have used the natural logarithmic value these variables in estimation of model. The present study has used data for the post liberalization period i.e. during 1991 to 2019.

To examine the relationship between FDI and manufacturing output in India, the study has employed the ARDL model proposed by McNown et al. (2018). Though there are various co-integration techniques such as Johansen (1988), Engle-Granger (1987), and Johansen-Juselius (1990) available, which assumed a unique order of integration, whereas the ARDL model is more flexible in terms of order of integration. This model is applied if the study time series variables are of a different order of integration such as I(0) and $\mathrm{I}(1)$, but not applicable to variables of I(2). Moreover, it gives more options for the lag selection of variables and handles the endogeneity of variables, if any exist. McNown et al. (2018) proposed ARDL model is an upgraded version of the Pesaran et al. (2001) model, known as augmented ARDL, which is necessitated an additional t-test or F-test for significance level.

The ARDL model is as follows:

$$
\begin{aligned}
& \Delta l n M F I_{t}=\alpha_{1}+\sum_{i=1}^{p} \beta_{1} \Delta l n M F I_{t-i}+\sum_{i=1}^{q} \beta_{2} \Delta l n F D I_{t-i}+\gamma_{1} l n M F I_{t-1} \\
& +\gamma_{2} \ln F D I_{t-1}+\varepsilon_{t}
\end{aligned}
$$

Where, $\alpha_{1}$ is an intercept term, $\varepsilon_{t}$ is a white noise error term and, $\Delta$ is a first difference operator.

The summation terms indicate short-term dynamic relations, whereas, the terms with $\alpha_{s}$ shows

the long-term dynamic relations between the selected variables. Here, the null hypothesis is $\gamma_{1}=$ $\gamma_{2}=0$, which means there is no cointegration or long-run relationship between the study

variables that can be examined using the F-Test and t-test proposed by McNown et al. (2018). If the estimated F-stat is greater than the upper bound critical value, then the null hypothesis is rejected, which implies a long-run relationship exists between the variables. On the other hand, if the estimated F-stat is neither lower nor greater than the two critical values, then the relationship between variables is inconclusive.

The short-run dynamic relationship between study variables is examined using the error correction model (ECM) as follows: 


$$
\Delta \ln M F I_{t}=\alpha_{2}+\sum_{i=1}^{p} \delta_{1} \Delta \ln M F I_{t-i}+\sum_{i=1}^{q} \delta_{2} \Delta l n F D I_{t-i}+\theta E C T_{t-1}+\mu_{t}
$$

Where, the $\delta_{s}$ indicates the short-run dynamic coefficients, the ECT is the error correction term and $\theta$ shows the speed of adjustment, which lies between 0 to -1 , where, 0 implies no convergence towards equilibrium, and -1 indicates a perfect convergence. The stationary condition of the study variables has been checked by using the unit root tests such as Augmented Dickey and Fuller (ADF) test and Phillips-Peron (PP) test. The variables' natural logarithmic values have been used in the analysis.

\section{Results Discussion}

The manufacturing output is one of the important components of the index of industrial production (IIP) is recorded at 129.8 in the year 2020, which seems very strong in the production of basic metals (10.8\%), intermediate goods ( $8.8 \%)$, food products $(2.7 \%)$ and tobacco products $(2.9 \%)$ (RBI online database). If we look at the trends of FDI and MFI during 1991 and 2019 as shown in Figure-4, indicate that both the trends of FDI and MFI are rising upward, but the FDI trend is raising upward faster than the MFI trend. The FDI trend is highly fluctuating than the MFI trend in the study period.

The descriptive statistics of FDI and MFI variables indicate that both the mean and standard deviation values of FDI are higher than the MFI, which indicates the foreign direct investment has a higher average value and volatility in India in the study period (Table-2). The skewness values are negative, the kurtosis and Jarque-Bera values indicate the normal distribution of variables. The correlation coefficient value is 0.94 indicates a high positive correlation between FDI and MFI during the study period in India (Table-3).

\section{Table 2: Descriptive Statistics of FDI and MFI in India}

\begin{tabular}{|lll|}
\hline & LNMFI & LNFDI \\
\hline Mean & 4.066 & 10.437 \\
\hline Std. Dev. & 0.586 & 2.015 \\
\hline Skewness & -0.122 & -0.935 \\
\hline Kurtosis & 1.567 & 3.330 \\
\hline Jarque-Bera & 2.553 & 4.358 \\
\hline Probability & 0.279 & 0.113 \\
\hline Observations & 29 & 29 \\
\hline
\end{tabular}

Source: Authors estimation

\section{Table 3: Result of Correlation Coefficient}




\begin{tabular}{|lll|}
\hline & LNMFI & LNFDI \\
\hline LNMFI & 1 & 0.94 \\
\hline LNFDI & 0.94 & 1 \\
\hline
\end{tabular}

Source: Authors estimation

The estimation of a time series model needs optimal lag length, which is selected through the lag length selection criteria and the estimated results are reported in Table-4. It indicates that the lag selection criterion indicates that one is the optimum lag, which is used for the model estimation. The stationary conditions of both the study variables are checked by using the unit root tests such as ADF and PP, the results are reported in Table-5. It shows that FDI is stationary at the level values, whereas, the MFI is nonstationary at the level values but becomes stationary at the first difference in both intercepts, and intercept with the trend. Although the study variables are a mix of $\mathrm{I}(0)$ and $\mathrm{I}(1)$, the relationship between these variables is measured using the ARDL model bound test.

\section{Table 4: Results of Optimal Lag Length}

\begin{tabular}{ccccccc}
\hline \hline Lag & LogL & LR & FPE & AIC & SC & HQ \\
\hline \hline 0 & -28.28136 & NA & 0.032302 & 2.243064 & 2.339052 & 2.271606 \\
1 & 57.06774 & $151.7317^{*}$ & $7.82 \mathrm{e}-05^{\star}$ & $-3.782796^{*}$ & $-3.494832^{\star}$ & $-3.697169^{\star}$ \\
2 & 60.07431 & 4.899584 & $8.47 \mathrm{e}-05$ & -3.709208 & -3.229268 & -3.566497 \\
\hline \hline
\end{tabular}

* indicates lag order selected by the criterion

LR: sequential modified LR test statistic (each test at $5 \%$ level)

FPE: Final prediction error

AIC: Akaike information criterion

SC: Schwarz information criterion

HQ: Hannan-Quinn information criterion

Source: Authors estimation

\section{Table 5: Results of Unit Root test}

The estimated t-statistics values from Unit root (level)

\begin{tabular}{|c|c|c|c|c|}
\hline & \multicolumn{2}{|c|}{ Intercept alone } & \multicolumn{2}{|c|}{ Intercept + Trend } \\
\hline & $\mathrm{ADF}$ & PP & $\mathrm{ADF}$ & PP \\
\hline LNMFI & 1.89 & 1.29 & -2.29 & -2.20 \\
\hline LNFDI & $-4.63 *$ & $-4.63 *$ & $-4.85 *$ & $-4.95 *$ \\
\hline \multicolumn{5}{|c|}{ The estimated $t-$ statistic values from unit root test (First difference) } \\
\hline LNMFI & $-3.27 * *$ & $-3.26 * *$ & $-3.45 * * *$ & $-3.51 * * *$ \\
\hline
\end{tabular}


Notes: a. Critical values for unit root test ( ADF \& DF) are $-3.69(1 \%),-2.97(5 \%)$ and $-2.62(10 \%)$ without trend and $-4.37(1 \%),-3.60(5 \%)$ and $-3.24(10 \%)$ with trend. And for DF test critical values are $-2.66(1 \%)$, $-1.95(5 \%)$ and $-1.60(10 \%)$ without trend and $-3.77(1 \%),-3.19(5 \%)$ and $-2.89(10 \%)$ with trend.

b. *** and ${ }^{* * *}$ indicates stationarity respectively at $1 \%, 5 \%$ and $10 \%$ levels.

Source: Authors Computation using E-views 10 student version

The results of ARDL model bound test are reported in Table-6, indicates that the estimated F-stat value (54.09) is higher than the upper bound critical value at $1 \%$ level that means the existence of a long-run relationship between FDI and MFI in the study period. The ARDL model lag order is selected through the AIC that suggests the ARDL $(1,0)$ model is a better order than others.

\section{Table 6: Result of Bound Test}

\begin{tabular}{c|c|c|c}
\hline Critical Value & F-Statistics & Lower Bound Value & Upper Bound Value \\
\hline $10 \%$ & & 3.02 & 3.51 \\
$5 \%$ & \multirow{5}{5}{54.09} & 3.62 & 4.16 \\
$2.50 \%$ & & 4.18 & 4.79 \\
$1 \%$ & & 4.94 & 5.58 \\
\hline
\end{tabular}

Source: Authors estimated

The ARDL model results are reported in Table-7, which indicates all coefficients are significant at the $1 \%$ level. The cointegration results indicate the existence of long-run cointegration between FDI and MFI. To support the long-run cointegration between the study variables, we have estimated the short-term cointegration using the ARDL-VEC model, the results are reported in Table-8. The ECM coefficient value -0.18 is significant at the $1 \%$ level, which means there is short-run relationship between the FDI and MFI. Hence, the study found the existence of short-run and long-run cointegration between FDI and MFI in the study period.

\section{Table 7: ARDL Long-run Model}




\begin{tabular}{crrrr}
\hline \hline \multicolumn{5}{c}{ Conditional Error Correction Regression } \\
\hline \hline Variable & Coefficient & Std. Error & \multicolumn{1}{c}{ t-Statistic } & Prob. \\
\hline C & 0.165155 & 0.040141 & 4.114396 & 0.0004 \\
LNIMS(-1)* & -0.181469 & 0.032165 & -5.641720 & 0.0000 \\
LNFDI** & 0.059081 & 0.010615 & 5.565816 & 0.0000 \\
\hline \hline
\end{tabular}

* p-value incompatible with t-Bounds distribution.

** Variable interpreted as $Z=Z(-1)+D(Z)$.

Levels Equation

Case 2: Restricted Constant and No Trend

\begin{tabular}{ccccc}
\hline \hline Variable & Coefficient & Std. Error & t-Statistic & Prob. \\
\hline \hline LNFDI & 0.325571 & 0.017289 & 18.83099 & 0.0000 \\
C & 0.910101 & 0.189563 & 4.801059 & 0.0001 \\
\hline \hline
\end{tabular}

$E C=$ LNIMS $-\left(0.3256^{*}\right.$ LNFDI + 0.9101)

Source: Authors estimation

Table 8: ARDL Error Correction Model

ECM Regression

Case 2: Restricted Constant and No Trend

\begin{tabular}{lcccr}
\hline \hline \multicolumn{1}{c}{ Variable } & Coefficient & Std. Error & t-Statistic & Prob. \\
\hline \hline \multicolumn{1}{c}{ CointEq(-1)* } & -0.181469 & 0.013708 & -13.23813 & 0.0000 \\
\hline \hline R-squared & 0.562760 & Mean dependent var & 0.060911 \\
Adjusted R-squared & 0.562760 & S.D. dependent var & 0.041122 \\
S.E. of regression & 0.027192 & Akaike info criterion & -4.336737 \\
Sum squared resid & 0.019964 & Schwarz criterion & -4.289158 \\
Log likelihood & 61.71432 & Hannan-Quinn criter. & -4.322192 \\
Durbin-Watson stat & 1.830049 & & \\
\hline \hline
\end{tabular}

* p-value incompatible with t-Bounds distribution.

Source: Authors estimation

\section{Conclusion}

This paper has examined the relationship between FDI and manufacturing output in India during the post liberalization period i.e. from 1991 to 2019 using the ARDL model. The study finds that the trends of FDI and MFI are rising but the FDI trend is more fluctuating than the MFI trend. The empirical results confirm a positive correlation between the FDI and MFI. The FDI is stationary at the level values, whereas, the MFI is non-stationary at the level values but becomes stationary at the first difference in both intercepts, and intercept with the trend. The ARDL bound test results indicate that the estimated F-stat value (54.09) is higher than the upper bound critical value of $1 \%$ level that means the existence of a long-run relationship between FDI and MFI in the study period. The study also finds a short-run cointegration from the ARDLVEC model. Since, the FDI plays an important role to breeze the gap between domestic savings and investment, there should have policy formulated by the government to attract more FDI to the country. 
Therefore, the present study suggests that the government has to attract more FDI by providing certain facilities like; good environment for business investment, proper implementation of corporate laws and taxation, and create new investment opportunities in the manufacturing sector.

\section{Declarations}

\section{Acknowledgements}

The authors are grateful to Prof. Jagannath Lenka for his valuable suggestions for improvement of the paper. We are also grateful to the anonymous referees for their valuable suggestions to improve the quality of the paper.

\section{Authors' contributions}

The findings of the paper is an addition to the existing literature on the relationship between foreign direct investment and manufacturing output. In addition to that the paper suggests policy implications which will help the larger investment in manufacturing sector and boost the output.

\section{Declaration of Conflicting Interests}

The authors declare that there is no conflict of interest of this study, authorship and publication of this paper.

\section{Funding}

The authors have not received any financial support from any sources for the study and publication of this paper.

\section{Availability of Data and Materials}

The data used in this paper for model estimation and analysis of results are publicly available at the Reserve bank of India and National Sample Survey Organisation online database.

\section{References}

1. Afolabi, A., Laseinde, O.T., Oluwafemi, I.J, Atolagbe, O.D., and Oluwafemi, J.F. (2012) Correlation between Manufacturing Sectors and Foreign Direct Investment. Journal of Physics: Conference Series, 1378, 032005.

2. Agrawal, P. (2005) Foreign Direct Investment in South Asia: Impact on Economic Growth and Local Investment. Multinationals and Foreign Investment in Economic Development. In: Graham EM (ed) Multinationals and foreign investment in economic development. Palgrave Macmillan, Basingstoke, pp 94-118. 
3. Alderson, A. (1997) Globalization and Deindustrialization: Direct Investment and the Decline of Manufacturing Employment in 17 OECD Nations. Journal of World Systems Research, Vol. 3, pp. 134.

4. Anowor, Oluchukwu, F., Ukweni, Nnaemeka, O., Ibiam, F. O., Ezekwem, Ogochukwu, S. (2013) Foreign Direct Investment and Manufacturing sector growth in Nigeria. International Journal of Advanced Scientific and Technical Research, 3(5).

5. Chandran,V.G.R., Krishnan,G. (2008) Foreign direct investment and manufacturing growth: The Malaysian experience. International Business Research. 1 (3).

6. Dash, k. Rajan., Parida, P.C. (2013) FDI, Service trade and Economic growth in India: Empirical evidence on causal links. Empirical Economics, 45 : 217-238.

7. Directorate of Economics and Statistics (2017) Index of Industrial Production 2016-17. Government of Karnataka, India.

8. Engle, R.F. and Granger, C.W.J. (1987) Cointegration and Error Correction: Representation, Estimation, and Testing. Econometrica, Vol. 55 (2), 251-276.

9. Epaphra, M. (2017) The Effect of Corruption on Foreign Direct Investment: A Panel Data Study. Turkish Economic Review, Vol. 4 (1), 19-54.

10. Eregha, P.B. (2012) The Dynamic Linkages between, Foreign Direct Investment and Domestic Investment in ECOWAS Countries: A Panel Cointegration Analysis. African Development Review, Vol. 24 (3), 208-220.

11. Hooda, S. (2011) A study on FDI and Indian Economy. Doctoral thesis, National Institute of Technology, Kurukshetra, Haryana.

12. Hussain, M. E. and Haque, M. (2016) Foreign Direct Investment, Trade, and Economic Growth: An Empirical Analysis of Bangladesh. Economies, Vol 4 (2), 1-14.

13. Index Mundi (n.d). Foreign direct investment, net outflows (\% of GDP).

14. Indian Industry Report, 2020.

15. Johansen S, Juselius K (1990) Maximum likelihood estimation and inference on cointegration-with applications to the demand for money. Oxford Bulletin of Economics and Statistics, 52:169-210.

16. Johansen, S. (1988) Statistical Analysis of Cointegration Vectors", Journal of Economic Dynamics and Control. Vol. 12 (2-3), 231-254.

17. Kathuria, S. (1986) Handicrafts Exports: An Indian Case Study. Economic and Political Weekly, Vol. $21(40), 1743-55$.

18. Kobrin, S.J. (2005) The Determinants of Liberalization of FDI Policy in Developing Countries: A Cross-Sectional Analysis, 1992-2001. Transnational Corporations, 14, 67-104.

19. Liu,K., Daly,K. (2011) Foreign direct investment in China manufacturing industry - transformation from a low tech to high tech manufacturing. International Journal of Business and Management, 6 (7). 
20. McNown, R., Yan. C. and Sam \& Soo. (2018) Bootstrapping the Autoregressive Distributed Lag test for Cointegration. Applied Economics, Vol. 50 (13), 1509-1521.

21. Ministry of Statistics \& Programme Implementation (2019-20) First Revised Estimates of National Income, Consumption Expenditure, Saving and Capital Formation. Government of India.

22. Mohanty, S. and Sethi, N. (2019) Does Inward FDI Lead to Export Performance in India? An Empirical Investigation. Global Business Review, 1-16.

23. Mwakanemela, K. (2014) Impact of FDI Inflows, Trade Openness and Inflation on the Manufacturing Export Performance of Tanzania: An Econometric Study. International Journal of Academic Research in Economics and Management Sciences, 3(5), 151-165.

24. Oyatoye, E. O., Arogundade, K. K., Adebisi, S. O., \& Oluwakayode, E. (2011) Foreign direct investment, export and economic growth in Nigeria. Journal of Humanities and Social Sciences, 2 (1).

25. Pesaran, M. H., Shin, Y. and Smith, R. (2001) Bounds testing approaches to the analysis of level relationships. Journal of Applied Econometrics, 16, pp. 289-326.

26. Turkan, B., Duman, A., and Yetkiner, I.H. (2008) How does FDI and economic growth affect each other? The OECD case. In International Conference on Emerging Economic Issues in a Globalizing World, pp. 21-40.

27. UNCTAD. World Development Report 2019- Special Economic Zones. United Nations, Geneva, 2019.

28. Wong, H.T. (2005) The determinants of foreign direct investment in the manufacturing industry of Malaysia. Journal of Economics Cooperation, 26 (2).

\section{Figures}

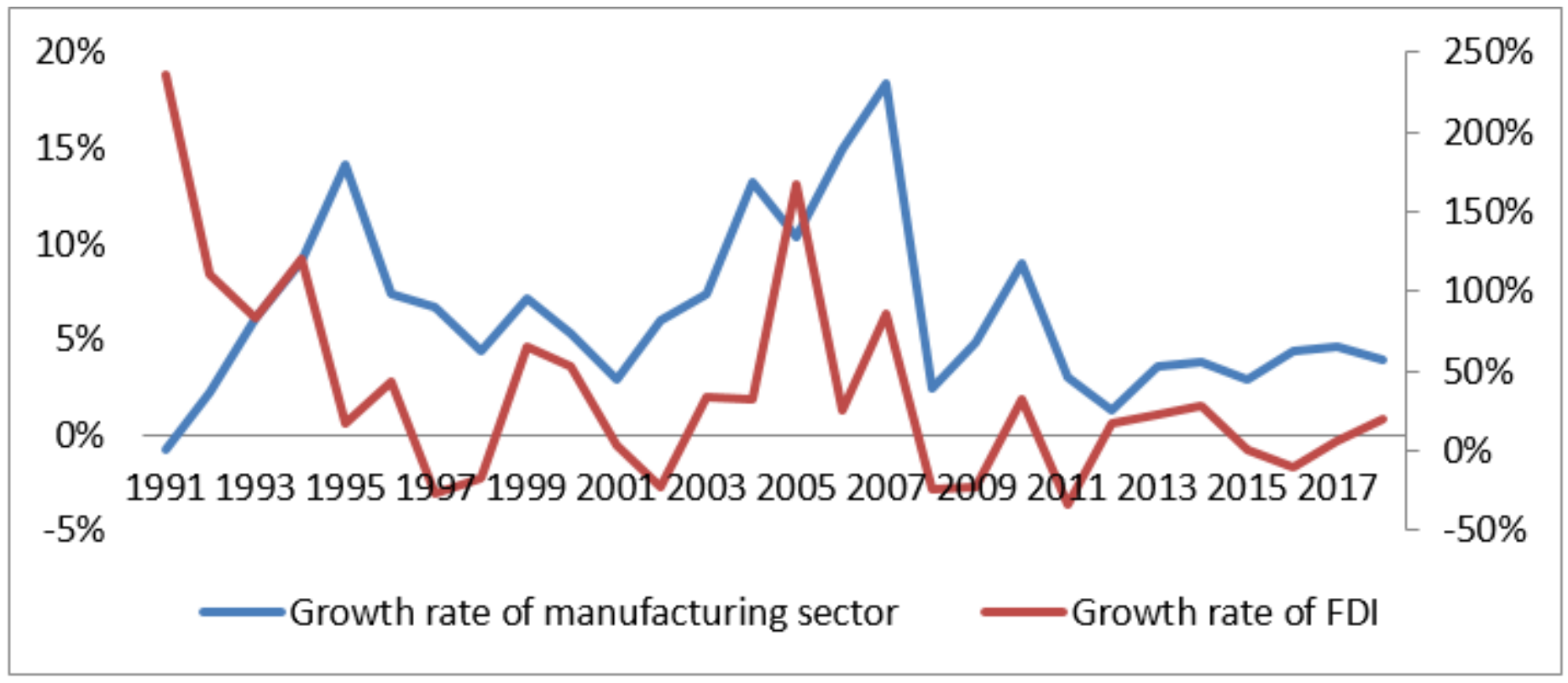

Figure 1

Trends of FDI and manufacturing sector in India during 1991-2018 
Source: Authors estimation by using RBI database data

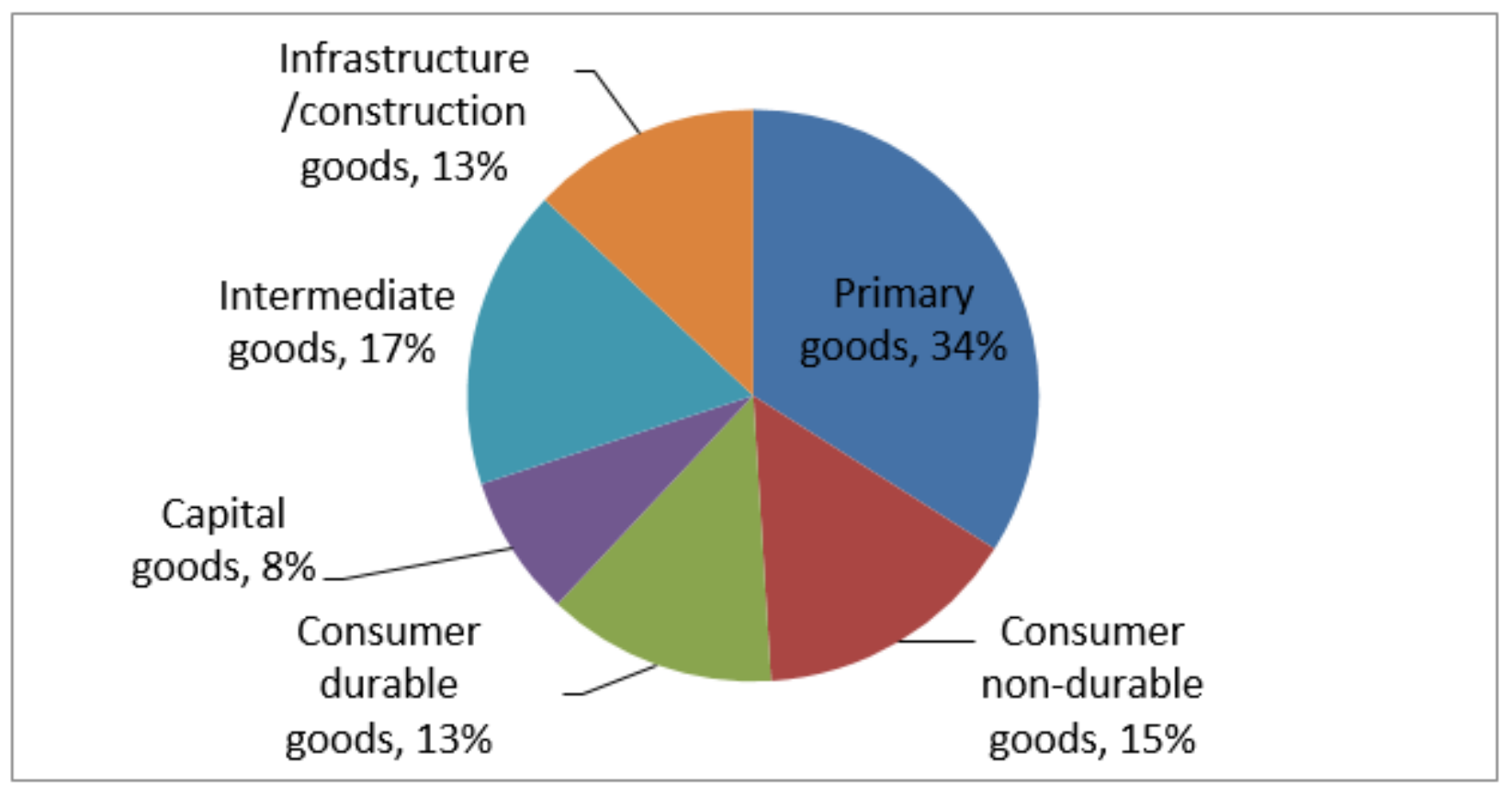

Figure 2

Uses of manufacturing output in India

Source: Authors estimated

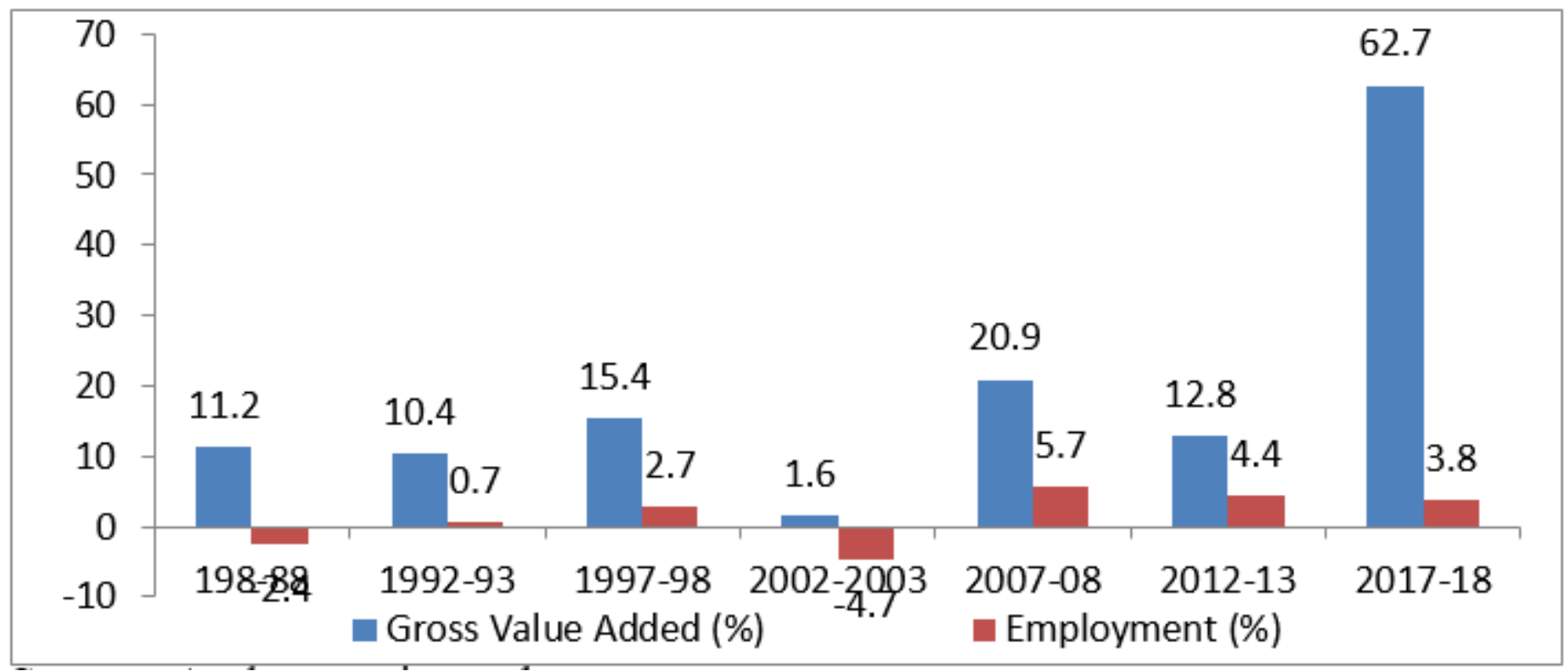

Figure 3

Trends of GVA and Employment in the manufacturing sector in India 


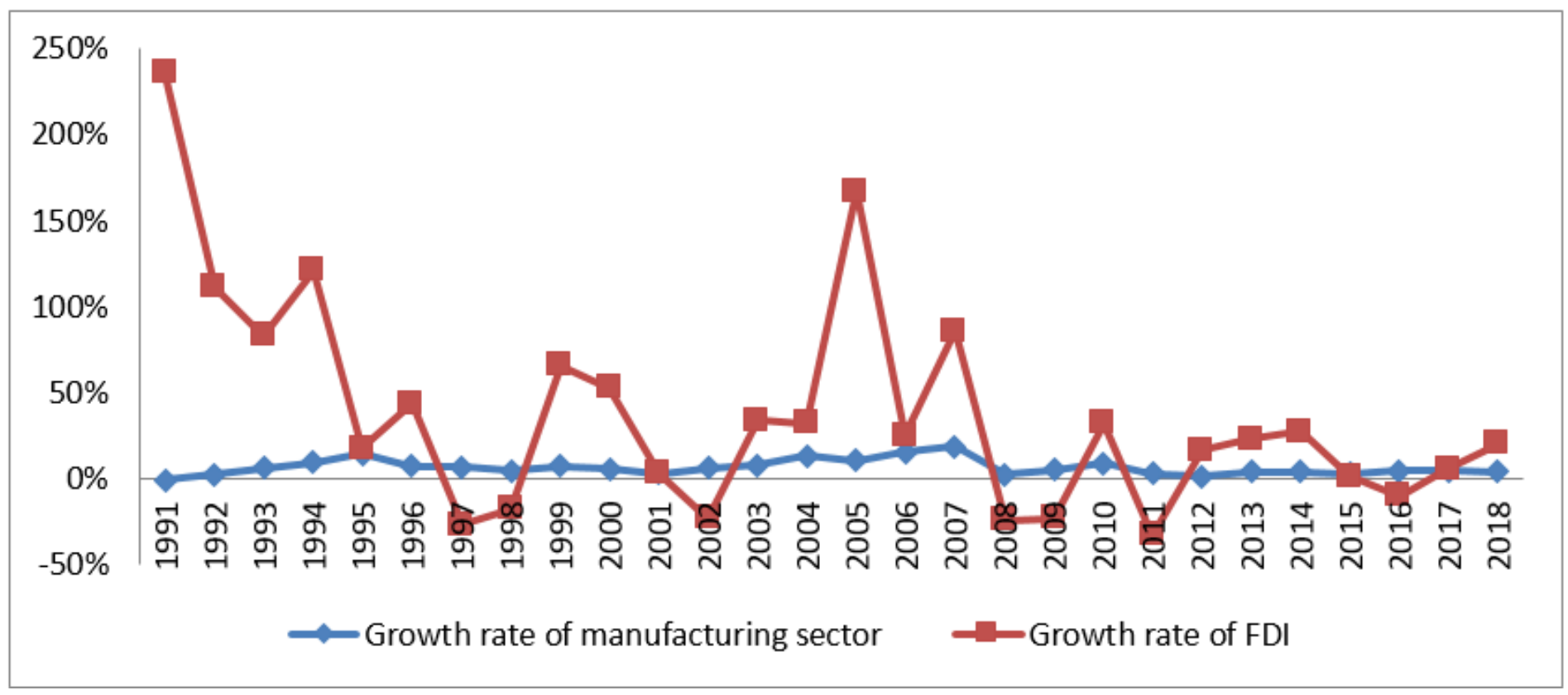

Figure 4

Trends of FDI and manufacturing sector in India during 1991-2018

Source: Authors estimation by using RBI database data 